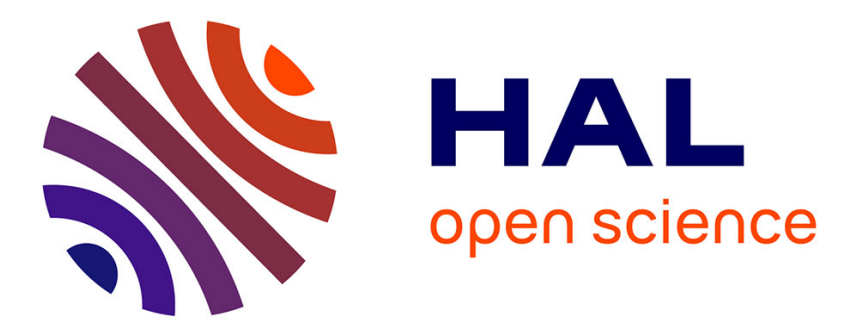

\title{
On Some Variants in Ashkenazic Biblical Manuscripts from the 12th and 13th Centuries
}

Elodie Attia

\section{To cite this version:}

Elodie Attia. On Some Variants in Ashkenazic Biblical Manuscripts from the 12th and 13th Centuries. Aaron Hornkohl; Geoffrey Khan. Studies in Semitic Vocalisation and Reading Traditions, 3, Open Book Publishers, pp.593-616, 2020, Semitic Languages and Cultures, 9781783749379. 10.11647/OBP.0207.14 . hal-02568307v2

\section{HAL Id: hal-02568307 \\ https://hal.science/hal-02568307v2}

Submitted on 4 Jun 2020

HAL is a multi-disciplinary open access archive for the deposit and dissemination of scientific research documents, whether they are published or not. The documents may come from teaching and research institutions in France or abroad, or from public or private research centers.
L'archive ouverte pluridisciplinaire $\mathbf{H A L}$, est destinée au dépôt et à la diffusion de documents scientifiques de niveau recherche, publiés ou non, émanant des établissements d'enseignement et de recherche français ou étrangers, des laboratoires publics ou privés. 


\section{Studies in Semitic Vocalisation and Reading Traditions}

\section{Edtted by Aaron D. Hornkohl and Geoffrey Khan}

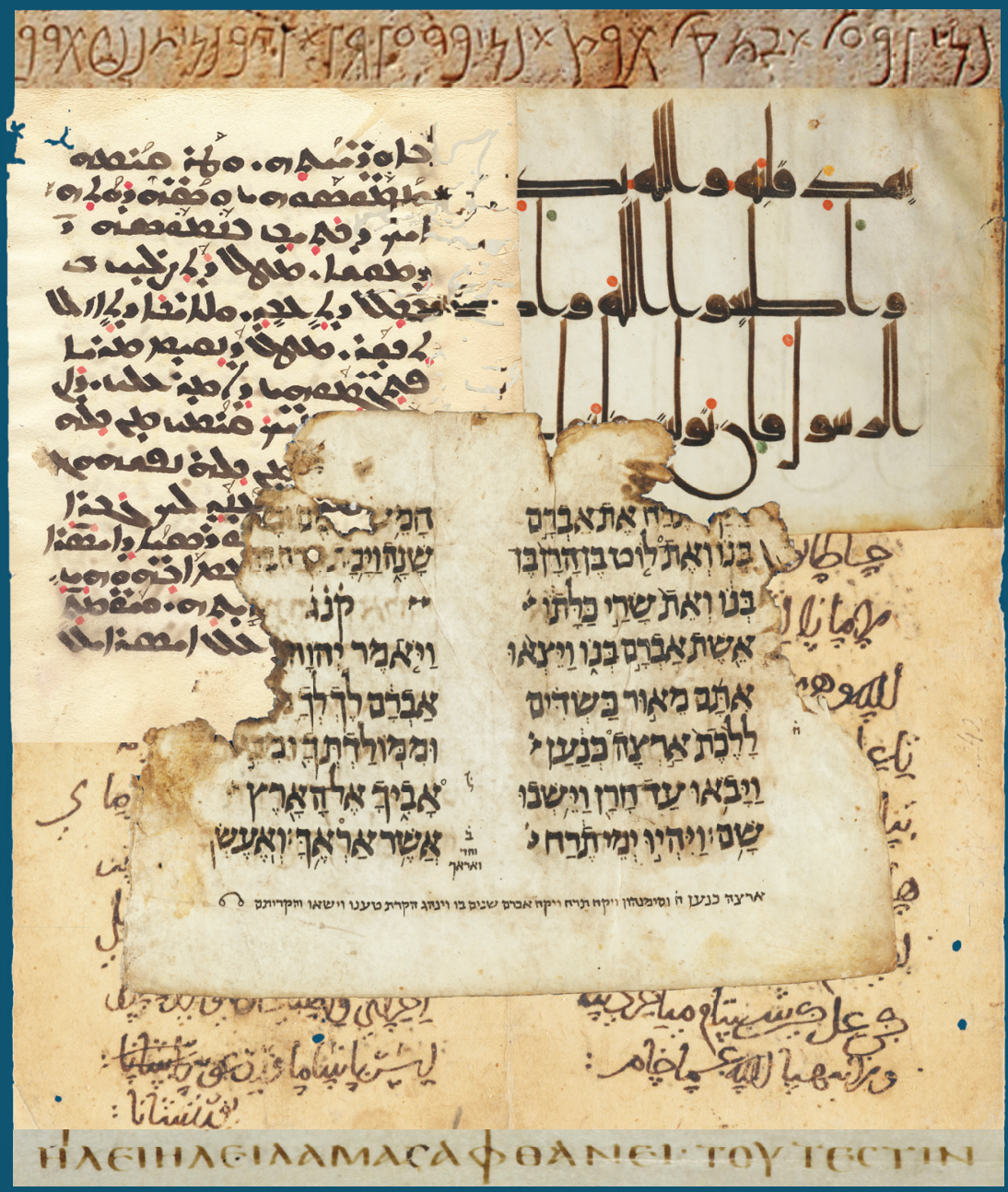




\section{https://www.openbookpublishers.com}

(C) 2020 Aaron D. Hornkohl and Geoffrey Khan. Copyright of individual chapters is maintained by the chapters' authors.

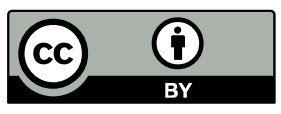

This work is licensed under a Creative Commons Attribution 4.0 International license (CC BY 4.0). This license allows you to share, copy, distribute and transmit the text; to adapt the text and to make commercial use of the text providing attribution is made to the authors (but not in any way that suggests that they endorse you or your use of the work). Attribution should include the following information:

Aaron D. Hornkohl and Geoffrey Khan (eds.), Studies in Semitic Vocalisation and Reading Traditions. Cambridge, UK: Open Book Publishers, 2020, https://doi.org/10.11647/OBP.0207

In order to access detailed and updated information on the license, please visit, https:// doi.org/10.11647/OBP.0207\#copyright

Further details about CC BY licenses are available at, https://creativecommons.org/ licenses/by/4.0/

All external links were active at the time of publication unless otherwise stated and have been archived via the Internet Archive Wayback Machine at https://archive.org/web

Updated digital material and resources associated with this volume are available at https://doi.org/10.11647/OBP.0207\#resources

Every effort has been made to identify and contact copyright holders and any omission or error will be corrected if notification is made to the publisher.

Semitic Languages and Cultures 3.

ISSN (print): 2632-6906

ISSN (digital): 2632-6914
ISBN Paperback: 978-1-78374-935-5

ISBN Hardback: 978-1-78374-936-2

ISBN Digital (PDF): 978-1-78374-937-9

DOI: $10.11647 / \mathrm{OBP} .0207$

Cover image: Detail from a bilingual Latin-Punic inscription at the theatre at Lepcis Magna, IRT 321 (accessed from https://it.wikipedia.org/wiki/File:Inscription_Theatre_ Leptis_Magna_Libya.JPG). Leaf of a Syriac prayer book with Western vocalisation signs (source: Wikimedia Commons). Leaf of an Abbasid-era Qurān (vv. 64.11-12) with red, yellow, and green vocalisation dots (source: Wikimedia Commons). Genizah fragment of the Hebrew Bible (Gen. 11-12, Cambridge University Library T-S A1.56; courtesy of the Syndics of Cambridge University Library). Genizah fragment of a Karaite transcription of the Hebrew Bible in Arabic script (Num. 14.22-24, 40-42, Cambridge University Library T-S Ar. 52.242; courtesy of the Syndics of Cambridge University Library). Greek transcription of the Hebrew for Ps. 22.2a in Matt. 27.46 as found in Codex Bezae (fol. 99v; courtesy of the Syndics of Cambridge University Library).

Cover design: Anna Gatti 


\title{
ON SOME VARIANTS IN ASHKENAZIC BIBLICAL MANUSCRIPTS FROM THE TWELFTH AND THIRTEENTH CENTURIES
}

\author{
Élodie Attia
}

À Philippe Cassuto, trop tôt disparu.

\subsection{Comparative Study BetWeen ORIENTal, SePhaR- DIC AND ASHKENAZIC MANUSCRIPTS}

In 1977, Frederico Pérez Castro published a detailed article entitled "Códices bíblicos hebreos. Evaluación comparativa de varios manuscritos toledanos, askenazíes y orientales," which focused on variants in medieval biblical manuscripts. The article aimed to "determine in a systematic way the quality of Sephardic manuscripts produced in the scriptoria of Toledo" (Pérez Castro 1977,

\footnotetext{
" Aix Marseille Univ, CNRS, TDMAM, Aix-en-Provence, France. This article was produced within the framework of the ANR Project Manuscripta Bibliae Hebraicae ( $\mathrm{N}^{\circ}$ ANR-16-ACHN-0008-01) at Aix-Marseille University, CNRS, TDMAM, Aix-en-Provence, France. I wish to thank my colleagues for the discussions around these results at the Vocalisation Workshop at the University of Cambridge (held in May 2017) and also at the Research Seminar on Semitic Linguistics held at the IREMAM, Aix-Marseille University (MMSH, October 2017).
} 
107). It sought to determine how close the late medieval Sephardic tradition was to the so-called 'Ben Asher tradition' or 'Tiberian Masoretic tradition'. ${ }^{1}$

Pérez Castro's study compared Sephardic manuscripts with early Tiberian manuscripts following the Ben Asher tradition and Ashkenazic manuscripts in order to identify differences between them. For that purpose, seven manuscripts were collated. First of all, a group of oriental Ben Asher (standard Tiberian Masoretic tradition) manuscripts, including:

a) the Leningrad Codex (MS St. Petersburg, National Library of Russia, I Firkovitch Evr. I B 19a, henceforth L) as the central comparative source, ${ }^{2}$ dated 1008/1009, the most complete early Masoretic manuscript of the Hebrew Bible; ${ }^{3}$

b) the manuscript London, British Library, Or. 4445 (henceforth $\mathrm{O}$ ), a Pentateuch the dating of which is still debatedthe script has been attributed to ninth-tenth-century Persia; ${ }^{4}$ some scholars agree with C. D. Ginsburg that the consonantal text could predate the tenth century, while its Masorah could have been made at the time of Aharon ben

${ }^{1}$ See Dotan (1977); Golinets (2012, 589); Khan (2013).

${ }^{2}$ On the manuscript, see Beit-Arié, Sirat, and Glatzer (1997, 114-31). Some editions, such as the Hebrew University Bible Project, take the Aleppo Codex as referent for the Standard Tiberian tradition. On the HUBP see Segal (2013) and on editions of the Hebrew Bible, see Lange and $\operatorname{Tov}(2016,113$, n. 4).

${ }^{3}$ Beit-Arié, Sirat and Glatzer (1997, i).

${ }^{4}$ Dotan (1993). 
Asher (who is mentioned as still living in some Masoretic annotations);

c) the Cairo Codex of the Prophets, dated to 894/895 (henceforth C). ${ }^{5}$

As far as the non-oriental manuscripts analysed are concerned, the Sephardic manuscripts included in the case study are:

d) the M1 Complutensian of Madrid, with the estimated date 1280, from the Toledo school, ${ }^{6}$ the basis of the Complutensian Bible of $1520 ;^{7}$

e) the JTS 44a Hilleli Codex (a Spanish codex supposed to have been copied from a lost codex of the seventh century called Codex Hilleli), dated $1241 .^{8}$

The Ashkenazic area is represented by:

f) MSS Paris, BnF, hébreu 1-3, dated 1289-end of the thirteenth century, Germano-Ashkenazic script; ${ }^{9}$ and

g) G-I-1 from the Escorial, dated 1306, probably not copied in Chersin, according to Pérez Castro, but in Flavignac, which is geographically near the present day lieu-dit Les Cars, in

\footnotetext{
${ }^{5}$ Beit-Arié, Sirat, and Glatzer (1997, MS 1, 25-39).

${ }^{6}$ See Del Barco (2003, MS 1). Its origin from Castilla may be doubtful according to Javier del Barco (private correspondence, 15 January 2014).

${ }^{7}$ Fernández Tejero (1976).

${ }^{8}$ Ortega Monasterio and Fernández Tejero (2005).

${ }^{9}$ Del Barco (2011, 20-27).
} 
Western France. This is corroborated by the Franco-Ashkenazic type of square script used by the scribe. ${ }^{10}$

Although the reasons for Pérez Castro's choice of Oriental and Sephardic manuscripts are clear (famous standard Tiberian codices or codices used for sixteenth-century editions), in the case of the Ashkenazic sources chosen there are regrettably no easy explanations: dating from the end of the thirteenth century and the beginning of the fourteenth century, the two items were not the earliest, but may have simply been available for research as microfilms.

${ }^{10}$ An alphabetical Masorah written in fols. $380 v-387 \mathrm{r}$ gives the Colophon of the MS Escorial G-I-1 and mentions the name of place. The Sfardata Database (Description Key OS014) mentions " פילאוינק היושבת [Flavignac?]" Flavignac is indeed located near Limoges in Haute-Vienne (Aquitaine, France). In support of this interpretation, the parish of Flavignac includes a smaller lieu-dit called 'Les Cars' three km from the village of Flavignac. I personally read במדינת קיארצין as 'in Carsins' village' (i.e., the inhabitants of the place nowadays called 'Les Cars', a name in a plural form that justifies the plural in Hebrew). Javier del Barco, in his catalogue (Del Barco del Barco 2003, 140), suggests a reading which fails to persuade us (בילאוינק קיארצין). Pérez Castro (1975, 109) suggested "escrito en Pilawoinaq, de la provincia de Chersin," which would lead us to think of a Ukrainian region (Cherson) proposed by our colleague Viktor Golinets. But the French type of script visible from the samples available in Sfardata does not confirm Pérez Castro's hypothesis. A verification will be made and the result set up in an online description of this manuscripts on the MBH Project Database, see https://www.mbhproject.org/). 
Pérez Castro's article gathered 826 lemmas by comparing ten verses from each biblical book in $\mathrm{L}$ with the other manuscripts. The results of this investigation showed, in the case of the Sephardic items, "a greater closeness to the Ben Asher tradition, [whilst] the Ashkenazic manuscripts are far removed ('se alejan muchissimo') from the Ben Asher model (here represented by L, O and C)" (Pérez Castro 1977, 160).

The conclusion of the article leads to the idea that Sephardic manuscripts are very close to the Ben Asher standard tradition, a point commonly shared nowadays, as it was already claimed in the thirteenth century by some Ashkenazic grammarians, such as Yequti'el ha-Naqdan in his 'En ha-Qore. ${ }^{11}$ Although the method employed in the article (comparing variants) is beyond reproach, the question of the treatment of the Ashkenazic manuscripts must be reassessed by taking into account the following facts:

a) Tiberian codices already vary among themselves-the best example is that, according to Pérez Castro's data, the Cairo Codex of the Prophets itself varies to almost the same extent as G-I-1 (one of the two selected Ashkenazic manuscripts) when both sets are compared to L (Pérez Castro, 1977, 159).

b) The unexplained choice of Ashkenazic manuscripts implies (without explicitly saying so) that MSS Paris 1-3 reflect the

${ }^{11}$ See Yarkoni's (1965) PhD dissertation and Yarkoni (1993). I thank Samuel Blapp for having brought these references to my attention. 
Palestino-Tiberian vocalization system or the so-called 'extended Tiberian' vocalization system. ${ }^{12}$ This system, described by Dotan as a nonconventional Tiberian system, requires further study, as it seems to exist in many variations across Ashkenazic Bible manuscripts. MSS Paris 1-3 and GI-I should not be taken as standard models for this cultural area and for general conclusions, but only as samples for preliminary conclusions. ${ }^{13}$

c) Other systematically analysed Ashkenazic manuscripts may lead to a reappraisal according to which non-Sephardic manuscripts are seen not just as philologically deviant from the standard tradition or as products of ignorance, as claimed by certain grammarians, ${ }^{14}$ but rather as being what they are: historical artefacts that reflect a different chain of post-Masoretic transmission of the Hebrew biblical text in Europe. Historically, these manuscripts have been used by Jews in European communities, copied with care from the exemplars on hand. ${ }^{15}$

${ }^{12}$ Golinets (2012, 596); for the background see Khan (2017).

${ }^{13}$ As there were no systematic studies of the Ashkenazic Bibles, Pérez Castro, of course, had no choice but to take samples. The ANR MBH project (2016-2020) will provide new data on this corpus of Ashkenazic biblical manuscripts.

${ }^{14}$ Yequti'el ha-Naqdan refers to this according to Yarkoni (1965, II:x).

${ }^{15}$ See, for instance, fol. 256r in MS Vat. Ebr. 14 (on which, see below), במסורת ישן נושן מוגה where Elijah ha-Naqdan mentions the reading found 'in an old masoret, old corrected examplar (?)'; cf. Attia (2015, 109-111, 125). 


\subsection{COMPARING TIBERIAN STANDARD MANUSCRIPTS WITH ASHKENAZIC MANUSCRIPTS}

Between 2011 and 2014, within the framework of a project at Heidelberg University, ${ }^{16}$ I prepared an edition of micrographic Masoretic notes appearing in MS Vatican, Biblioteca Apostolica Vaticana, Vat. Ebr. $14 .{ }^{17}$ This manuscript is a Norman-Ashkenazic Bible that contains only the Pentateuch, the Five Megillot and the Haftarot (extracts of the Prophets). This codex was produced in Normandy in 1239 by a scribe named Elijah ha-Naqdan. ${ }^{18}$ I will not discuss here the point of editing figurative Masorah-an enterprise considered non-philological per se by many scholarsbut rather focus on a new question: How do the earliest Ashkenazic manuscripts correspond to the Tiberian Masoretic text?

The present analysis is not structured in exactly the same way as that of Pérez Castro, but some parallels can be drawn. The basis of this new analysis is the Ashkenazic Bible MS Vat. Ebr. 14 mentioned above. This manuscript preserves 63 folios of figurative Masorah, namely, drawings and figures made up of text (see illustration below). In this case study I have chosen to focus on thirteen folios from Exodus. In each folio (which do not always

\footnotetext{
${ }^{16}$ SFB 933 Materialen Text-Kulturen, Subproject B4, with Prof. H. Liss (HFJS), Kay Petzold, Sebastian Seeman.

${ }^{17}$ See Attia (2015).

${ }^{18}$ See Attia (2015, Appendix 2, Codicological and Palaeographical Description of MS Vat. Ebr. 14, 119-30) and also in the MBH Database.
} 
present continuous text), the lemmas of words that are the subject of a masora parva (MP) or a masora magna (MM) are edited. For each lemma, MP variants and MM variants are recorded.

The lemmas of MS Vat. Ebr. 14 have been compared with those of seven other manuscripts divided into two groups: a group of four standard Tiberian manuscripts and a group of three of the earliest Ashkenazic manuscripts. The standard Tiberian group of Hebrew biblical manuscripts include here:

(i) The so called 'Leningrad Codex', i.e., the MS Saint Petersburg, National Library of Russia, I Firkovitch, B19a (henceforth $\mathrm{L}$ ).

(ii) The MS London, British Library, Or. 4445 (henceforth O)

(iii) The so called ' $\mathrm{M} 1$ ', i.e. the MS Madrid, Complutense University Library 118-Z-42 [M1], (henceforth M), a thirteenth-century Sefardic Bible.

(iv) The so called 'Damascus Pentateuch', i.e., the MS Jerusalem, National Library of Israel, $24^{\circ} 5702$, (henceforth D). This is a Pentateuch dated to the tenth century, with some notes vocalized and accented according to the Babylonian system.

The 'Aleppo Codex' has not been chosen, because it does not include Exodus. ${ }^{19}$

The corpus of Ashkenazic manuscripts is composed of some of the earliest dated Ashkenazic Bibles (unlike the corpus of Pérez Castro), namely:

${ }^{19} \mathrm{http} / / /$ www.aleppocodex.org/newsite/index.html 
(i) MS London, Valmadonna Trust 1 (henceforth V). This is the earliest dated Ashkenazic Bible, 1189, only 180 years older than $\mathrm{L}$.

(ii) MS Berlin, Statsbibliothek zu Berlin, Or. Qu. 9, 1233 (henceforth B). This was written by Elijah ha-Naqdan in a very small format, with Masoretic notes in a MM presented in an abbreviated manner. It appears to be a miniaturization of Vat. Ebr. 14. ${ }^{20}$

(iii) MS Vatican, Biblioteca Apostolica Vaticana, Vat. Ebr. 482 (henceforth R). This is one of the famous 'La Rochelle Bibles', copied in La Rochelle on the Atlantic coast, probably in 1216. The Prophets and the Hagiographs were copied by the same scribe who wrote the MS Vatican, Vat. Ebr. 468 (La Rochelle, 1215). It is a complete Bible, with Targum in the margins of the Pentateuch. ${ }^{21}$

Due to the large number of variations in the use of rafe between the manuscripts considered here, as well as some practical and technical editorial problems, it has been decided to mark rafe in the lemma when it appears in the lemma, but not to record variant uses of the rafe.

\footnotetext{
${ }^{20}$ See Attia (2015, Appendix 3, Codicological and Palaeographical Description of MS Berlin Or. Qu. 9, 131-37).

${ }^{21}$ A new paleographical analysis of Vat. Ebr. 482 is in preparation, based on the software Graphoskop, examining the possibility that this manuscript is the product of two different scribes.
} 
Following this procedure, in the thirteen folios studied in my monograph The Masorah of Elijah ha Naqdan (2015), 162 lemmas were found having a MP and/or MM. These present seventy variants. In the table below, I have applied the classification devised by Pérez Castro to my own list of variants.

\begin{tabular}{|c|c|c|c|}
\hline $\begin{array}{c}\text { Folio } \\
\text { in Attia } \\
(2015)\end{array}$ & $\begin{array}{c}\text { No. of lem- } \\
\text { mas with MP } \\
\text { and/or MM }\end{array}$ & $\begin{array}{c}\text { Variants in } \\
\text { lemma, MP, } \\
\text { and/or MM }\end{array}$ & $\begin{array}{c}\text { Variants in consonantal } \\
\text { form, plene vs. defective } \\
\text { spellings, ketiv-qere }\end{array}$ \\
\hline 1 & 14 & 8 & 1 \\
\hline 2 & 17 & 10 & 1 \\
\hline 3 & 7 & 2 & 0 \\
\hline 4 & 12 & 6 & 3 \\
\hline 5 & 14 & 8 & 2 \\
\hline 6 & 17 & 4 & 1 \\
\hline 7 & 11 & 6 & 0 \\
\hline 8 & 5 & 2 & 0 \\
\hline 9 & 13 & 5 & 0 \\
\hline 10 & 17 & 5 & 0 \\
\hline 11 & 17 & 6 & 0 \\
\hline 12 & 10 & 6 & 0 \\
\hline 13 & 8 & 2 & $\mathbf{8}$ \\
\hline TOTAL & $\mathbf{1 6 2}$ & $\mathbf{7 0}$ & \\
\hline
\end{tabular}

Based on this procedure, the distribution of variants is similar to the one in Pérez Castro's study (see table below). These include:

(i) a few variants in terms of consonantal form, plene versus defective spelling, and ketiv-qere; 
(ii) some vowel interchanges, including, as in Pérez Castro's study, the replacement of shureq with qibbus and patah with qames;

(iii) many variants concerning accents;

(iv) variations in the marking of $g a^{c} y a$.

\begin{tabular}{|c|c|c|c|}
\hline $\begin{array}{c}\text { Folio in Attia } \\
\text { (2015) }\end{array}$ & $\begin{array}{c}\text { Variants in vo- } \\
\text { calisation }\end{array}$ & $\begin{array}{c}\text { Variants in accents, } \\
\text { dagesh, rafe }\end{array}$ & $\begin{array}{c}\text { Variants } \\
\text { in gacya }\end{array}$ \\
\hline 1 & 2 & 4 & 2 \\
\hline 2 & 2 & 6 & 2 \\
\hline 3 & 0 & 2 & 0 \\
\hline 4 & 2 & 3 & 0 \\
\hline 5 & 2 & 3 & 1 \\
\hline 6 & 0 & 3 & 0 \\
\hline 7 & 0 & 4 & 2 \\
\hline 8 & 1 & 0 & 2 \\
\hline 9 & 0 & 3 & 0 \\
\hline 10 & 0 & 5 & 1 \\
\hline 11 & 1 & 4 & 1 \\
\hline 12 & 1 & 4 & $\mathbf{1 3}$ \\
\hline 13 & 2 & 0 & 2 \\
\hline TOTAL (67*) & $\mathbf{1 3}$ & $\mathbf{4 1}$ & \\
\hline
\end{tabular}

* Three variants cannot be classified according to these categories.

\subsection{SELECT EXAMPLES}

Key to table

| Separator between variants

$=\quad$ This case in Vat14 is the same in $\mathrm{X}$

$\sim \quad$ This case in Vat14 appears as variant in $\mathrm{X}$ 
$<\quad$ This case in Vat14 is not found in $\mathrm{X}$

// 'corresponding to'

3.1. Variants in Consonantal Form, Plene versus Defective Spelling, and Ketiv-Qere

\begin{tabular}{|c|c|c|}
\hline & MS Vat. Ebr. 14 & $\begin{array}{l}\text { Apparatus repro- } \\
\text { duced from Attia } \\
(2015)\end{array}$ \\
\hline 1 & $\begin{array}{l}\text { ויישם ק Iil Gen. } 50.26 \\
\text { Different spelling and a ketiv-qere MP } \\
\text { shared only by Vat14, V and B, }{ }^{22} \text { matching } \\
\text { Tiberian codices }\end{array}$ & 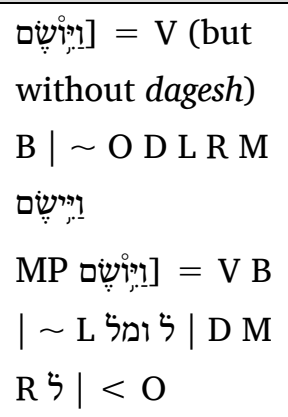 \\
\hline 2 & $\begin{array}{l}\text { Exyod. } 5.14 \\
\text { Defective spelling only in Vat14; plene } \\
\text { spelling in Ashk. mss V and B but B does } \\
\text { not have a disjunctive accent. }\end{array}$ & 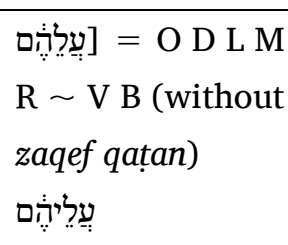 \\
\hline 3 & 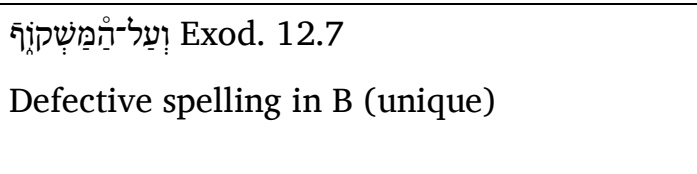 & 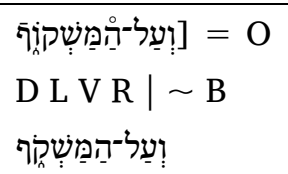 \\
\hline
\end{tabular}

${ }^{22}$ Additional research on this form in other manuscripts shows that in the MS St John's College, Cambridge, MS A1, the reading in this precise passage follows Vat14, B and V. 


\begin{tabular}{|c|c|c|}
\hline 4 & 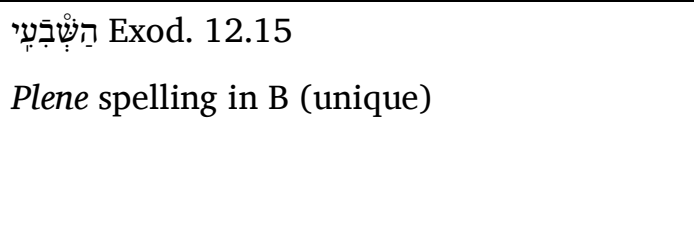 & 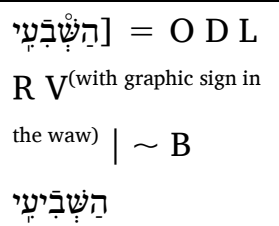 \\
\hline 5 & $\begin{array}{l}\text { Exod. } 12.16 \\
\text { Specific accents in Vat14; V displays a de- } \\
\text { fective spelling. }\end{array}$ & 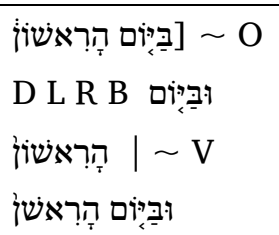 \\
\hline 6 & 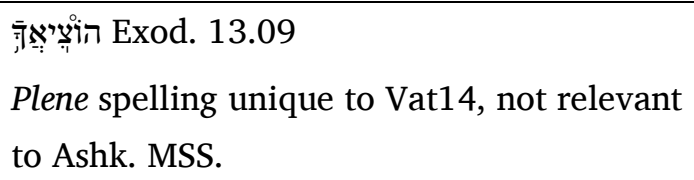 & 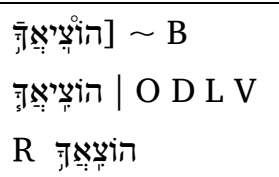 \\
\hline 7 & 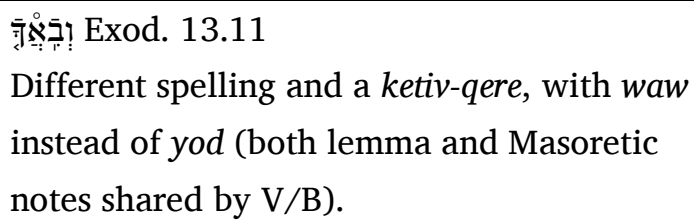 & 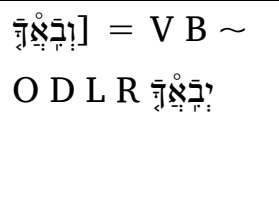 \\
\hline 8 & 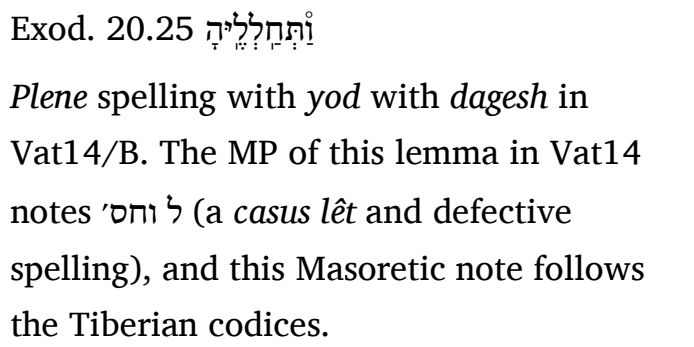 & 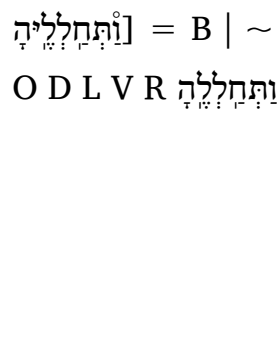 \\
\hline
\end{tabular}

\subsection{Vowels}

\subsubsection{Shureq/qibbus Interchange}

\begin{tabular}{|c|c|c|}
\hline 9 & $\begin{array}{l}\text { In Bxod. } 12.11 \\
\text { In B qibbus (short) replaced by a } \\
\text { shureq (long). }\end{array}$ & 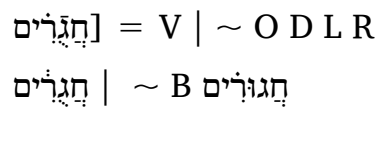 \\
\hline
\end{tabular}




\begin{tabular}{|c|c|c|}
\hline 10 & 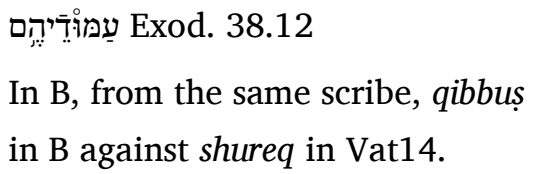 & 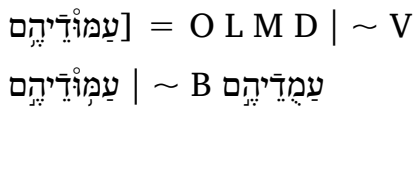 \\
\hline 11 & 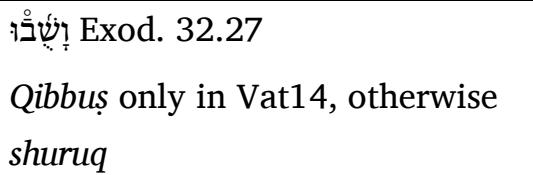 & 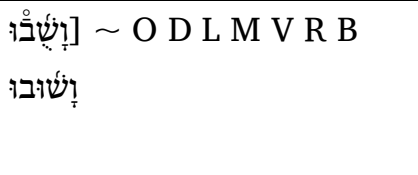 \\
\hline
\end{tabular}

\subsubsection{Pataḥ/qameș Interchange}

\begin{tabular}{|c|c|c|}
\hline 12 & 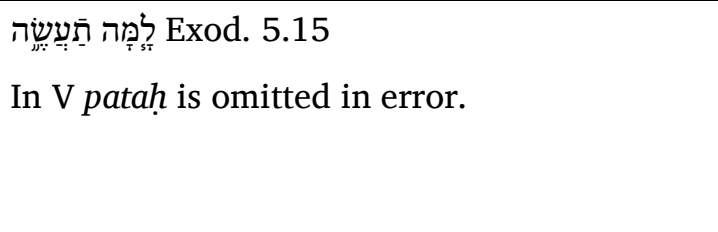 & 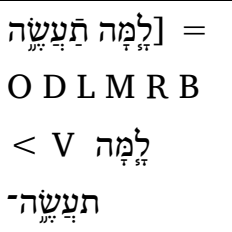 \\
\hline 13 & 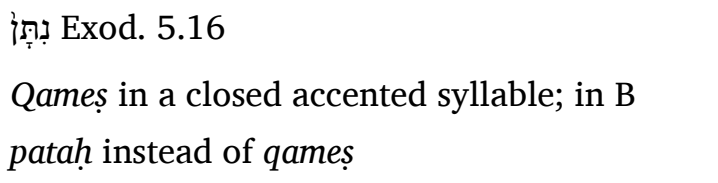 & 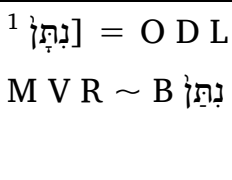 \\
\hline 14 & $\begin{array}{l}\text { נָָָ Exod. } 13.17 \\
\text { Distinctive feature of B (patah instead of } \\
\text { qameș), munah replaced by merkha. }\end{array}$ & 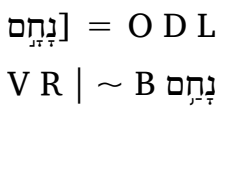 \\
\hline 15 & $\begin{array}{l}\text { Exod. } 40.38 \\
\text { Patah in the lemma (this form is indicated in } \\
\text { an additional MP note in Vat14 as one of four } \\
\text { exceptions in the Pentateuch); replaced in B } \\
\text { by qames without an accent sign. }\end{array}$ & 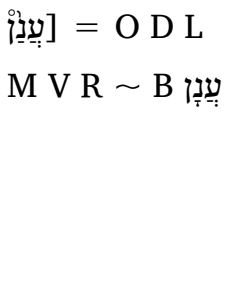 \\
\hline
\end{tabular}




\subsubsection{Other Cases}

\begin{tabular}{|c|c|c|}
\hline 16 & 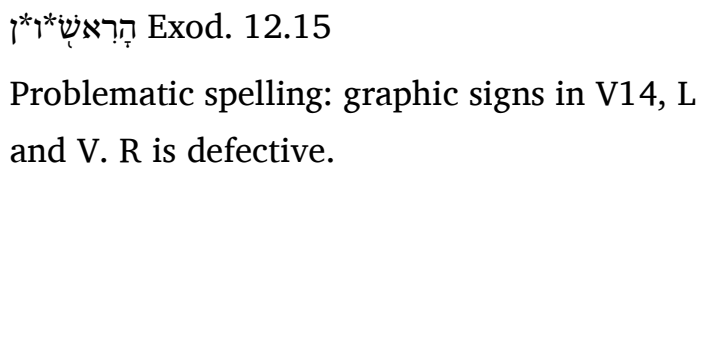 & 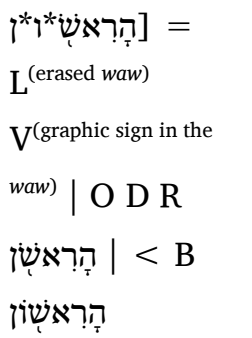 \\
\hline 17 & $\begin{array}{l}\text { Iְכָ Exod. } 13.13 \\
\text { Vowel qameṣ qațan in Ashkenazic MSS // ḥo- } \\
\text { lem haser in Tiberian MSS. }\end{array}$ & 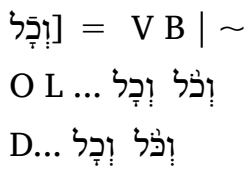 \\
\hline 18 & $\begin{array}{l}\text { לָא Ex Exod. } 35.9 \\
\text { In Tiberian manuscripts plene spelling; in An- } \\
\text { glo-Norman manuscripts (Vat14, V, B and } \\
\text { others }{ }^{23} \text { ) defective spelling (holem haser) with } \\
\text { an accompanying Masorah note. Vat14's MP } \\
\text { and MM figurata refer to three defective } \\
\text { cases, while there is a lack of agreement with } \\
\text { the masorah of Tiberian codices, which men- } \\
\text { tions three cases, two plene and one defec- } \\
\text { tive. }\end{array}$ & 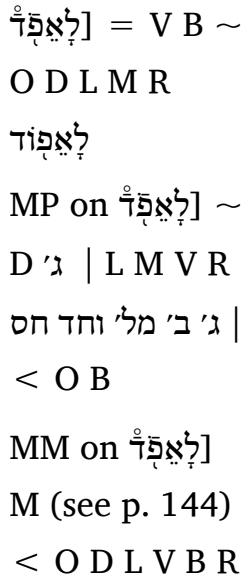 \\
\hline
\end{tabular}

${ }^{23}$ This lemma in Vat14 is indeed three times defective: Exod. 25.7; 35.9, 27. The same is true in $\mathrm{V}$ and $\mathrm{B}$, and also in the Ashkenazic manuscript MS. BL Or. 4227 (dated to 1300). In V the lemma follows the AngloNorman group, but its MP (ג'ב' מל' וחד חס) refers to the Tiberian codices O, D, L and R (where only Exod. 25.7 is defective). See Attia (2015, 101

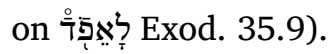




\begin{tabular}{|c|c|c|}
\hline 19 & 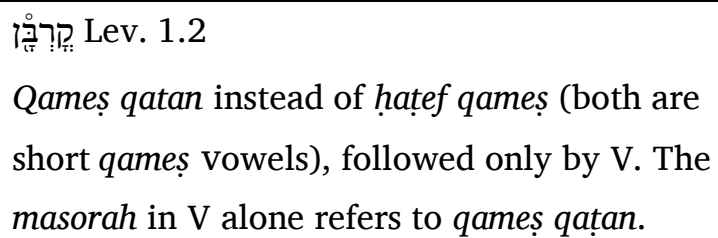 & 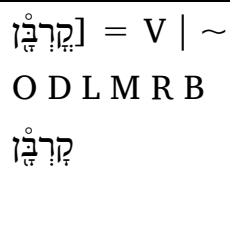 \\
\hline
\end{tabular}

\subsection{Accents and Diacritical Signs}

In this category B is the manuscript that generally exhibits differences.

\subsubsection{Erroneously Omitted or Differently-placed Dagesh}

\begin{tabular}{|c|c|c|}
\hline 20 & $\begin{array}{l}\text { Absence of dagesh in B. } 50.23 \\
\text { Aִרְָּּ Gen. }\end{array}$ & 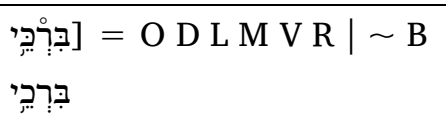 \\
\hline 21 & $\begin{array}{l}\text { Dagesh different in B (in the la- } 1.7 \\
\text { med) (mistake?). }\end{array}$ & 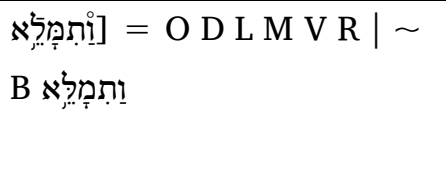 \\
\hline 22 & $\begin{array}{l}\text { Dagesh omitted in B (same } 5.13 \\
\text { scribe). }\end{array}$ & בַלֶּו \\
\hline 23 & $\begin{array}{l}\text { ינ: Exod. } 13.17 \\
\text { Absence of dagesh in B. }\end{array}$ & 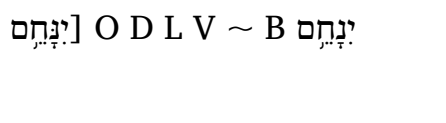 \\
\hline 24 & 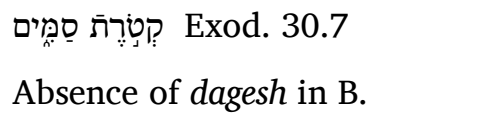 & 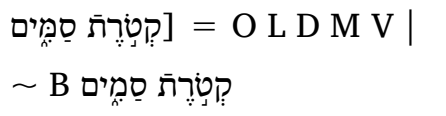 \\
\hline
\end{tabular}

\subsubsection{Isolated Variants in the Accents}

\begin{tabular}{|c|c|c|}
\hline 25 & $\begin{array}{l}\text { וְאֶל־הַזְקְנְנִ Exod. } 24.14 \\
\text { Accent changed in B. }\end{array}$ & 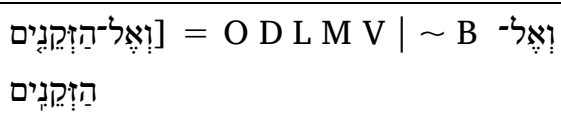 \\
\hline
\end{tabular}




\begin{tabular}{|c|c|c|}
\hline 26 & $\begin{array}{l}\text { Iוּיְְּּן Exod. } 24.16 \\
\text { Accent changed in B. }\end{array}$ & 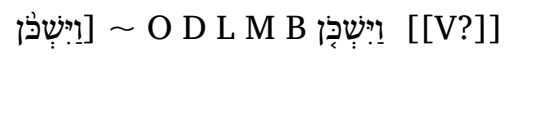 \\
\hline 27 & $\begin{array}{l}\text { Expod. } 24.17 \\
\text { Absence of accent in } \\
\text { B. }\end{array}$ & 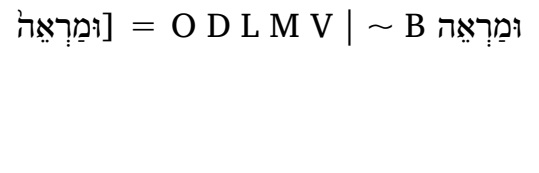 \\
\hline 28 & $\begin{array}{l}\text { Eִ ְִי־קְחוּ Exod. } 25.2 \\
\text { Accent changed in B. }\end{array}$ & 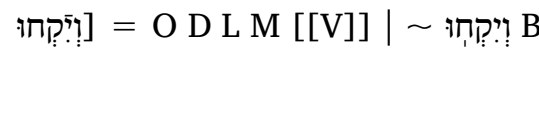 \\
\hline
\end{tabular}

\subsubsection{Word-final Shewa}

Valmadonna 1 includes the isolated feature of shewa on wordfinal yod and waw.

\begin{tabular}{|c|c|c|}
\hline 29 & $\begin{array}{l}\text { V וּבְָאָח Exod. } 32.29 \\
\text { v with shewa on final } \\
\text { waw. }\end{array}$ & 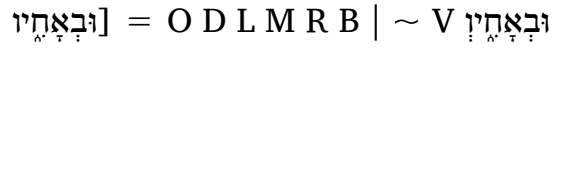 \\
\hline 30 & 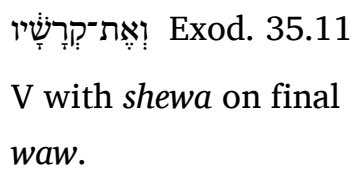 & 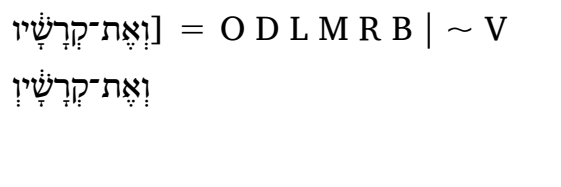 \\
\hline 31 & $\begin{array}{l}\text { Exod } 35.11 \\
\text { V with shewa on final } \\
\text { waw. }\end{array}$ & 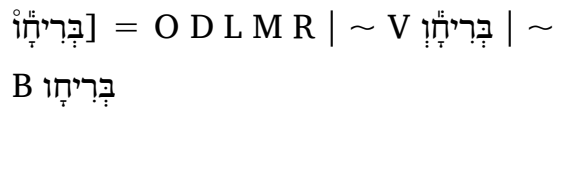 \\
\hline 32 & $\begin{array}{l}\text { וְאֶ Exod. } 35.12 \\
\text { V with shewa on final } \\
\text { waw. }\end{array}$ & בַּדָּין \\
\hline
\end{tabular}

\subsubsection{Variants Shared by Ashkenazic Manuscripts}

Four variants are shared by at least two manuscripts of the Ashkenazic Group Vat14/B/V (R generally follows L, O and D). 


\begin{tabular}{|c|c|c|}
\hline 33 & 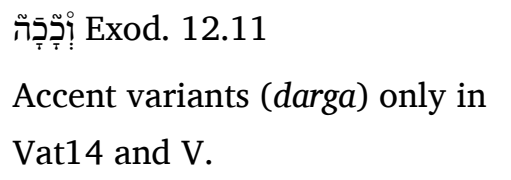 & וְכָכָה ] \\
\hline 34 & 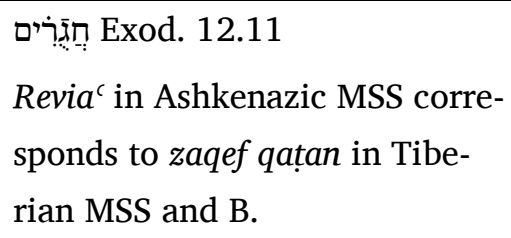 & 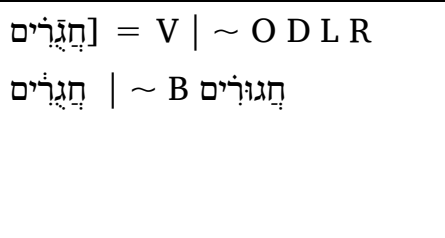 \\
\hline 35 & $\begin{array}{l}\text { לִ Exod. } 13.10 \\
\text { Ashkenazic MSS have mappiq } \\
\text { below the he and not inside. }\end{array}$ & 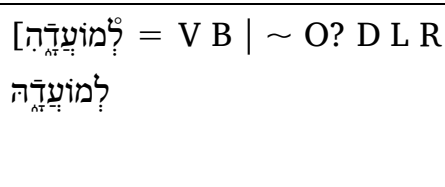 \\
\hline 36 & 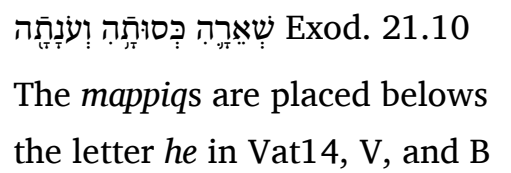 & 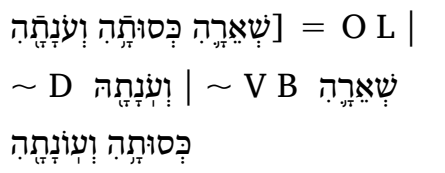 \\
\hline
\end{tabular}

\subsubsection{Ga'ya}

Many variants involve the absence of gacya in B.

\begin{tabular}{|c|c|c|}
\hline 37 & 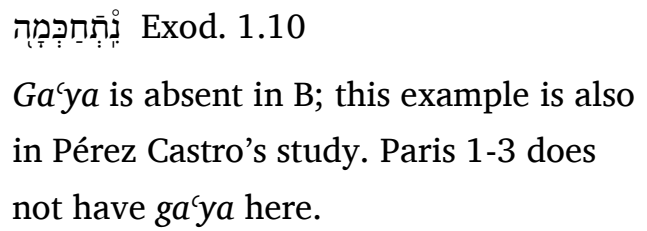 & 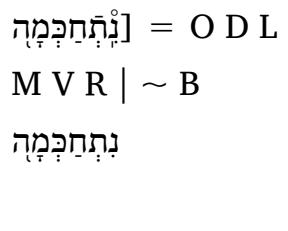 \\
\hline 38 & $\begin{array}{l}\text { צxyed. Exod. } 5.8 \\
\text { Absence of } g a \text { ' } y a \text {; present only in D, L, } \\
\text { and V. }\end{array}$ & 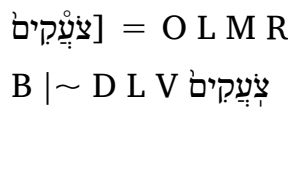 \\
\hline
\end{tabular}

\subsection{CONCLUDING REMARKS}

These new data show that when Tiberian sources, such as the Damascus Pentateuch and earlier Ashkenazic Bible manuscripts, 
are added to the comparative corpus, the question of the relationship of the Ashkenazic manuscripts to the Ben Asher tradition becomes more complicated than previously believed by scholars. The Tiberian Ben Asher vocalisation tradition cannot be reduced to L. Irregularity in the variants shows that more than one model was followed and that even among the oriental Tiberian codices variants already existed. For instance, with regard to gacya, the ga $y a$ is absent from $\mathrm{O}$, but present in V. Hence, it may be concluded that the principles of the Tiberian Masoretic tradition were followed with varying degrees of faithfulness, as can only be expected in a manuscript culture.

The adjustments or disagreements between the Masoretic notes and the consonantal text remind us that a post-Masoretic medieval biblical manuscript is the result of a complex process involving sources and different people. The sofer was responsible for the consonants and may have used a different exemplar from that used by the naqdan or the masran. This is the case in Valmadonna 1, where many Masoretic annotations contradict the consonantal text. ${ }^{24}$ Moreover, some grammatical explanations offered by the grammarian Yequti'el ha-Naqdan in his 'En ha-Qore correspond to the variants I have described. ${ }^{25}$ It is highly likely, however, that, despite Yequti'el ha-Naqdan's opinion, the Ashke-

\footnotetext{
${ }^{24}$ See also Beit-Arié, Sirat, and Glatzer (2006, 82-87, especially 83).

${ }^{25}$ The second part of the work (a grammatical treatise) propounds rules for word-stress, methigot (i.e., ga'yas), maqqefs, and warnings against errors in the reading of a Sefer Torah (Yarkoni 1965, II:i-ii). Further research is required.
} 
nazic Bibles remain fundamentally Tiberian and should be considered a medieval development of that tradition. This forces us to abandon the idea of a monolithic 'standard' Tiberian tradition (or a family of manuscripts made up of L, O, and D) opposing a 'non-standard' or 'non-conventional' one. We should rather conceive of post-medieval Tiberian texts, including some groups of variants inspired by local pronunciations, customs, and scribal practices.

In addition, the study of the variants shows both specificities of each manuscript as well as families of manuscripts or scribal traditions. For instance, compared to Vat. Ebr. 14, La Rochelle shares fewer variants with Ashkenazic manuscripts (for in-

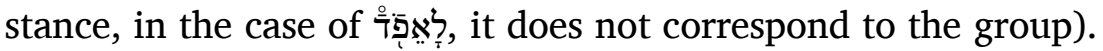
It is possible that this manuscript was copied from a Spanish exemplar in La Rochelle and not from an Ashkenazic one. ${ }^{26}$ Also, MS B is an odd case. This is a manuscript that appears to have been produced by the same scribe as wrote MS Vat. Ebr. 14. The codicological and palaeographical features reflect the same hand. MS B, however, follows different rules of vocalization from what are found in MS Vat. Ebr. 14, viz. the interchanges qames/patah and shureq/qibbus; omission of dagesh; gacya generally different from MS Vat. Ebr. 14. Why is this? The local pronunciation of Hebrew may have influenced early medieval Ashkenazic Bibles

\footnotetext{
${ }^{26}$ This manuscript seems to have been transported to Spain after 1294 (when the Jews were expelled from the town). See Richler and Beit-Arié (2008, 406-7).
} 
and prayer books. ${ }^{27}$ It is possible that MS B was copied from a different examplar. Moreover, its very small format suggests that it may have been intended for use as a prayer book.

One interesting hypothesis, supported by case 18 Exod. 35.9), is that manuscripts that exhibit the strongest AngloNorman variants, i.e., cases where MSS Vat. Ebr. 14, V, and B share similar variants, furnish evidence for the existence of a uniform scribal tradition as a subgroup within the Ashkenazic area. A group of Anglo-Norman variants emerged from this corpus, specifically in cases $1,2,4,7,17,18,19,33,35$ and 36 . In my opinion, this group could constitute a basis for further study on Ashkenazic Bibles from England or Northern France.

The Manuscripta Bibliae Hebraicae Project (MBH Project) seeks to study Ashkenazic biblical manuscripts in depth, linking textual features, such as the specific variants noted in the above group of Ashkenazic manuscripts, to extensive material features, such as codicological and palaeographical parameters. This should help us locate and reconstruct families of manuscripts and scribal traditions within western medieval Europe, as well as construct a new typology of medieval Hebrew biblical manuscripts in this geocultural area.

\subsection{REFERENCES}

Attia, Élodie. 2015. The Masorah of Elijah Ha-Naqdan: An Edition of Ashkenazi Micrographical Notes (Ms. Vat. Ebr. 14, Book of Exodus). Materiale Textkulturen. 11. Berlin: De Gruyter.

27 See Eldar $(1978,16)$ on qameș/patah interchanges; OlszowySchlanger $(2003,129)$. 
Beit-Arié, Malachi, Colette Sirat, and Mordechai Glatzer. 1997. Monumenta Palaeographica Medii Aevi, Codices Hebraicis Litteris Exarati Quo Tempore Scripti Fuerint Exhibentes: Tome I: Jusqu'à 1020. Monumenta Palaeographica Medii Aevi. Series Hebraica 1. Turnhout: Institut de recherche et d'histoire des textes, Paris, and ha-'Aqademya ha-Le'umit haYiśre’elit le-Mada'im, Jerusalem.

- 2006. Monumenta Palaeographica Medii Aevi, Codices Hebraicis Litteris Exarati Quo Tempore Scripti Fuerint Exhibentes: Tome IV: De 1144 à 1200. Monumenta Palaeographica Medii Aevi. Series Hebraica 4. Turnhout: Institut de recherche et d'histoire des textes, Paris, and ha-'Aqademya haLe'umit ha-Yiśre'elit le-Mada'im, Jerusalem.

Cohen, Menahem. 1986. 'The "Masoretic Text" and the Extent of Its Influence on the Transmission of the Biblical Text in the Middle Ages'. In Studies in Bible and Exegesis, vol. 2, edited by Uriel Simon, 229-56. Ramat Gan: Bar-Ilan University Press.

Del Barco del Barco, Francisco Javier. 2003. Catálogo de manuscritos hebreos de la comunidad de Madrid. Vol. 1: Manuscritos bíblicos, comentarios bíblicos de autor y obras gramaticales en las bibliotecas de El Escorial, Universidad Complutense de Madrid y Palacio Real. Madrid: Consejo Superior de Investigaciones Cientificos.

. 2011. Manuscrits en caractères hébreux conservés dans les bibliothèques de France: Catalogues. Vol. 4. Paris-Turnhout: BNF, Institut de Recherche et d'Histoire des Textes (CNRS) and Brepols. 
Dotan, Aron. 1977. 'Masorah'. Encyclopaedia Judaica 13. Online edition. Detroit: Macmillan Reference USA in association with the Keter.

- 1993. 'Reflections Towards a Critical Edition of Pentateuch Codex Or. 4445'. In Estudios Masoreticos Dedicados a Harry M. Orlinsky (V Congreso de la IOMS), edited by Emilia Fernández Tejero, 39-51. Estudios Masoreticos 10. Madrid: Consejo Superior de Investigaciones Cientificos.

Eldar, Ilan. 1978. The Hebrew Language Tradition in Medieval Ashkenaz (ca. 950-1350 C.E). Vol. 1: Phonology and Vocalization. Jerusalem: The Hebrew University of Jerusalem, The Institute of Jewish Studies, The Language Traditions Project.

Fernández Tejero, Emilia. 1976. La tradición textual española de la Biblia Hebrea: El manuscrito 118-Z-42 (M1) de la Biblioteca de la Universidad Complutense de Madrid. Madrid: Consejo Superior de Investigaciones Científicas.

Golinets, Viktor. 2012. 'Tiberian Masorah'. In Encyclopedia of Hebrew Language and Linguistics, edited by Geoffrey Khan. Leiden: Brill.

Khan, Geoffrey. 2013. A Short Introduction to the Tiberian Masoretic Bible and its Reading Tradition. Piscataway, NJ: Gorgias Press.

_ 2017. 'The Background of the So-called "Extended Tiberian" Vocalization of Hebrew'. Journal of Near Eastern Studies 76 (2): 265-73. 
Lange, Armin, and Emmanuel Tov. 2016. Textual History of the Bible. Vol. 1: The Hebrew Bible. Part A: Overview Articles. Leiden: Brill.

Olszowy-Schlanger, Judith. 2003. Les manuscrits hébreux dans l'Angleterre médievale: Étude historique et paléographique. Collection de la Revue des Études Juives 29. Paris: Peeters. Ortega Monasterio, María Teresa, and Emilia Fernández Tejero. 2005. 'Los códices modelo y los manuscritos hebreos bíblicos españoles'. Sefarad 2: 353-83.

Pérez Castro, Frederico. 1977. 'Códices bíblicos hebreos: Evaluación comparativa de varios manuscritos toledanos, askenazíes y orientales' Sefarad 37: 105-61.

Richler, B., and Malachi Beit-Arié, eds. 2008. Hebrew Manuscripts in the Vatican Library: Catalogue Compiled by the Staff of the Institute of Microfilmed Hebrew Manuscripts, Jewish National and University Library, Jerusalem. Studi e Testi 438. Vatican City: Biblioteca Apostolica Vaticana and Jerusalem: Makhon le-Tatslume Kitve-ha-Yad ha-'Ivriyim.

Segal, Michael. 2013. 'The Hebrew University Project Bible'. Hebrew Bible and Ancient Israel (HeBAI) 2: 38-62.

Yarkoni, Rivka. 1965. “"En Ha-Qore” by Yequti'el Ha-Naqdan'. PhD dissertation, Tel-Aviv University. - 1993. 'Yequti'el Ha-Naqdan-One of the Last Masoretes or an Early Ashkenazi Grammarian'. In Estudios Masoreticos Dedicados a Harry M. Orlinsky (V Congreso de la IOMS), edited by Emilia Fernández Tejero, 139-49. Estudios Masoreticos 10. Madrid: Consejo Superior de Investigaciones Cientificos. 